\title{
Supramolecular Interactions Involved in the Solid State Structure of $N, N^{\prime}$-[bis(pyridin-2-yl)formylidene]ethane-1,2-diamine
}

\author{
Arab K. El-Qisairi, ${ }^{\text {a,* }}$ Hanan A. Qaseer, ${ }^{a}$ Solhe F. Alshahateet, ${ }^{\text {a }}$ M. K. Hasan Qaseer, ${ }^{\text {b }}$ \\ Mukarram H. Zaghal, ${ }^{\mathrm{c}}$ Wa'el Al-Btoush, ${ }^{\mathrm{a}}$ and Louise N. Dawe ${ }^{\mathrm{d}}$

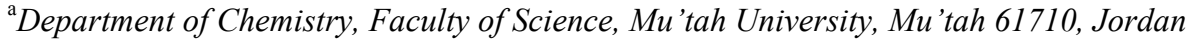 \\ ${ }^{\mathrm{b}}$ Department of Physics, Faculty of Science, Jordan University of Science and Technology, P.O.Box 3030, Irbid, Jordan \\ ${ }^{\mathrm{c}}$ Department of Chemistry, Faculty of Science, Yarmouk University, Irbid, Jordan \\ ${ }^{\mathrm{d}}$ Centre for Chemical Analysis, Research and Training, Memorial University of Newfoundland St. John's, \\ NL, A1B 3X7, Canada
}

RECEIVED MAY 3, 2013; REVISED FEBRUARY 5,2014; ACCEPTED FEBRUARY 25, 2014

\begin{abstract}
The structure of the symmetrical Schiff base, $N, N^{\top}$-[bis(pyridin-2-yl)formylidene]ethane-1,2diamine (bpfd) has been characterized by single crystal X-ray diffraction. The non-covalent supramolecular chemistry involved in the crystal structure of this ligand has been carefully investigated. The structure adopted different motifs of nitrogen-hydrogen interactions that led to the formation of centrosymmetric dimers. In addition, edge-edge and face-face nitrogen-nitrogen interactions were observed and reported. The Schiff base (bpfd) ligand crystallizes in a monoclinic space group C12/c1 with $a$ $=19.128(2) \AA ; b=5.8776(6) \AA ; c=13.1403(15) \AA ; \alpha=90^{\circ} ; \beta=121.970^{\circ}(4) ; \gamma=90^{\circ}$ and $z=4$. This structure is an example of compounds with many symmetry-independent molecules in the asymmetric unit cell $(Z>2)$.
\end{abstract}

Keywords: centrosymmetric dimer interactions, unit cell packing arrangement, spectral properties, high Zvalue structure

\section{INTRODUCTION}

Recently, there has been some interest in the preparation of various Schiff base ligands ${ }^{1}$ due to their preparative accessibilities, structural varieties and varied denticities. Metal-chelate Schiff base complexes have played an important role in developing stereochemical models in main group and transition metal coordination chemistry, mainly due to their stability, ease of preparation, and structural variability. ${ }^{2-6}$ Furthermore, they have been investigated for their ability to act as antibacterial agents, ${ }^{7-9}$ antifungal agents, ${ }^{10,11}$ antitumor drugs ${ }^{12-14}$ and catalysts. ${ }^{15-17}$ The $N, N^{\prime}$-[bis(pyridin-2-yl)formylidene]ethane-1,2-diamine (bpfd) ligand is among the ligands that have been studied and some of its complexes have been reported. ${ }^{1,18-23}$ As a part of our ongoing research into the structure and utility of Schiff base ligands, we report the crystal structure of $N, N^{\prime}$-[bis(pyridin-2yl)formylidene]ethane-1,2-diamine (bpfd) ligand, and study the supramolecular chemistry is based on noncovalent interactions involved in the crystal structure of (bpfd) ligand.

\section{EXPERIMENTAL}

\section{General Experimental}

All chemicals were purchased from Aldrich chemical company and used as received. The solvents used were AR grade. ${ }^{1} \mathrm{H}$ and ${ }^{13} \mathrm{C}$ NMR spectra were recorded in $\mathrm{CDCl}_{3}$ on a Brucker $400 \mathrm{MHz}$ at Jordan University of Science and Technology. Chemical shifts were referenced to tetramethylsilane (TMS). The infrared spectra were recorded on a Maltson 5000 FTIR spectrophotometer. Electronic absorption spectra were recorded on a Perkin Elmer Lambda $25 \mathrm{UV} / \mathrm{Vis}$ Spectrometer in dimethylsulfoxide (DMSO) using $1 \times 10^{-6} \mathrm{M}$ solution. The symmetrical Schiff base, $N, N^{\prime}$-[bis(pyridin-2yl)formylidene]ethane-1,2-diamine (bpfd) was prepared by refluxing ethane-1,2-diamine and pyridine-2carboxaldehyde in 1:2 mole ratio in absolute ethanol (Figure 1). ${ }^{24}$ The (bpfd) ligand was characterized by FTIR, UV-vis, ${ }^{1} \mathrm{H}$ and ${ }^{13} \mathrm{C}$ NMR spectroscopy. It was recrystallised from diethyl ether to give colourless crystals with X-ray quality.

\footnotetext{
* Author to whom correspondence should be addressed. (E-mail: aqaseer@mutah.edu.jo \& aqaseer2011@yahoo.com)
} 


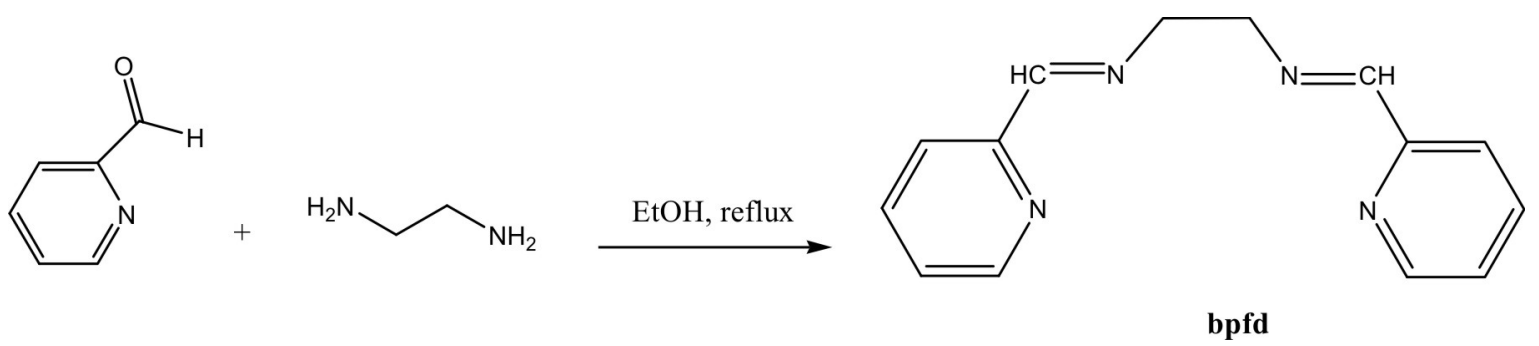

Figure 1. Preparation of bpfd ligand

\section{Preparation of $\mathrm{C}_{14} \mathrm{H}_{14} \mathrm{~N}_{4}$ (bpfd)}

To a stirred solution of ethylenediamine $(0.157 \mathrm{~g} ; 2.61$ $\mathrm{mmol})$ in $20 \mathrm{ml}$ ethanol, a solution of 2pyridinecarboxaldehyde $(0.560 \mathrm{~g} ; 5.23 \mathrm{mmol})$ in ethanol (5 ml) was added dropwise over a period of 1-2 hours. The reaction mixture was then stirred and refluxed for 24 hours. The mixture was evaporated and recrystallized from diethyl ether. The product was filtered and dried in oven at $40{ }^{\circ} \mathrm{C}$. The yield was $0.30 \mathrm{~g}(48 \%)$. The compound melted at $57-59{ }^{\circ} \mathrm{C}$. FTIR (neat, $\mathrm{cm}^{-1}$ ): 2920 $v(\mathrm{C}-\mathrm{H}$, aliphatic $), 1647 v(\mathrm{C}=\mathrm{N}$, imine $), 1586$, and 1427 $v(\mathrm{C}=\mathrm{N}$, and $\mathrm{C}=\mathrm{C}$ pyridine $)$. UV-vis; $\lambda_{\max }(\varepsilon): 272 \mathrm{~nm}$ $\left(22900 \mathrm{M}^{-1} \mathrm{~cm}^{-1}\right), 282\left(15500 \mathrm{M}^{-1} \mathrm{~cm}^{-1}\right) .{ }^{1} \mathrm{H}$ NMR $\left(400 \mathrm{MHz}, \mathrm{CDCl}_{3}\right): \delta=8.59(\mathrm{~d}, 2 \mathrm{H}, J=6.1), 8.40(\mathrm{~s}$, $2 \mathrm{H}), 7.95(\mathrm{~d}, 2 \mathrm{H}, J=6.1), 7.69(\mathrm{t}, 2 \mathrm{H}, J=7.6), 7.25(\mathrm{dt}$, $2 \mathrm{H}, J=1.6,6.1), 4.03(\mathrm{~s}, 4 \mathrm{H}) \mathrm{ppm} .{ }^{13} \mathrm{C}$ NMR $(100$ $\left.\mathrm{MHz}, \mathrm{CDCl}_{3}\right): \delta=61.3,121.3,124.4,136.5,149.3$, $154.3,163.2 \mathrm{ppm}$. The solid state structure of the (bpfd) ligand has been determined by single-crystal X-ray diffraction.

\section{Crystal Data}

$\begin{array}{ll}\begin{array}{l}\text { Empirical Formula } \\ \text { Formula Weight }\end{array} & \begin{array}{l}\mathrm{C}_{14} \mathrm{H}_{14} \mathrm{~N}_{4} \\ \text { Crystal Color, Habit }\end{array} \\ \begin{array}{l}\text { Crystal Dimensions } \\ \text { chunk, colorless }\end{array} & 0.80 \times 0.80 \mathrm{X} 0.78 \mathrm{~mm} \\ \text { Crystal System } & \text { monoclinic } \\ \text { Lattice Type } & \text { C-centered } \\ \text { Detector Position } & 40.03 \mathrm{~mm} \\ \text { Pixel Size } & 0.137 \mathrm{~mm} \\ & a=19.128(2) \AA \\ \text { Lattice Parameters } & b=5.8776(6) \AA \\ & c=13.1403(15) \AA \\ & \beta=121.970(4)^{\circ} \\ & V=1253.3(2) \AA^{3} \\ \text { Space Group } & \mathrm{C} 12 / \mathrm{c} 1 \\ Z \text { value } & 4\end{array}$

$\begin{array}{ll}D_{\text {calc }} & 1.263 \mathrm{~g} / \mathrm{cm}^{3} \\ F_{000} & 504 \\ \mu(\mathrm{MoK} \alpha) & 0.79 \mathrm{~cm}^{-1}\end{array}$

Intensity Measurements

Detector

Goniometer

Rigaku Saturn Rigaku AFC8

Radiation

$\operatorname{MoK} \alpha(\lambda=0.71070 \AA)$ graphite monochromated

Detector Aperture

$70 \mathrm{~mm} \times 70 \mathrm{~mm}$

Data Images

864 exposures

$\omega$ oscillation Range

$(\chi=0.0, \phi=0.0)$

$-75.0-105.0^{\circ}$

Exposure Rate

$22.0 \mathrm{sec} . /^{\circ}$

Detector Swing Angle

$15.08^{\circ}$

$\omega$ oscillation Range

$(\chi=0.0, \phi=180.0)$

$-45.0-75.0^{\circ}$

Exposure Rate

$22.0 \mathrm{sec} . /^{\circ}$

Detector Swing Angle

$15.08^{\circ}$

$\omega$ oscillation Range

$(\chi=45.0, \phi=90.0)$

$-42.0-90.0^{\circ}$

Exposure Rate

$22.0 \mathrm{sec} . /^{\circ}$

Detector Swing Angle

$15.08^{\circ}$

Detector Position

$40.00 \mathrm{~mm}$

Pixel Size

$0.068 \mathrm{~mm}$

$2 \theta_{\max }$

$80.6^{\circ}$

No. of Reflections Measured

Total: 2592

Unique: 1420

$\left(R_{\text {int }}=0.0214\right)$

Corrections Lorentz-polarization Secondary Extinction (coefficient: 0.0066(16))

Absorption

(trans. factors:0.9394-0.9408) 


\section{Structure Solution and Refinement}

Structure Solution

Direct Methods (SHELX97)

Refinement

Full-matrix least-squares on $F^{2}$

Function Minimized $\quad \Sigma w\left(\mathrm{Fo}^{2}-\mathrm{Fc}^{2}\right)^{2}$

Least Squares Weights $w=1 /\left[\sigma^{2}\left(\mathrm{Fo}^{2}\right)+(0.0202 \cdot P)^{2}\right.$ $+1.2836 \cdot P]$ where $P=\left(\operatorname{Max}\left(\mathrm{Fo}^{2}, 0\right)+\right.$ $\left.2 \mathrm{Fc}^{2}\right) / 3$

$2 \theta_{\max }$ cut off $55.0^{\circ}$

Anomalous Dispersion All non-hydrogen atoms No. Observations

(All reflections)

No. Variables 84

Reflection/Parameter

Ratio

16.90

Residuals: $R 1(I>2.00 \sigma(I))$

0.0458

Residuals: $R$ (All reflections)

Residuals: $w R 2$ (All reflections)

Goodness of Fit Indicator

Max Shift/Error in Final Cycle

0.000

Maximum peak in Final Diff. Map

$0.29 \mathrm{e}^{-} / \AA^{3}$

Minimum peak in Final Diff. Map

$-0.17 \mathrm{e}^{-} / \AA^{3}$

\section{Solution and Refinement of the Crystal Structure}

Single-crystal X-ray diffraction experiment was carried out on a Rigaku Saturn CCD area detector with graphite monochromate Mo-K $\alpha$ radiation. The data were collected at a temperature of $-135 \pm 1{ }^{\circ} \mathrm{C}$ to a maximum $2 \theta$ value of $80.6^{\circ}$. Data were collected and processed using Crystal Clear. ${ }^{25}$ The linear absorption coefficient, $\mu$, for Mo-K $\alpha$ radiation is $0.79 \mathrm{~cm}^{-1}$. A numerical absorption correction was applied which resulted in transmission factors ranging from 0.9394 to 0.9408 . The data were corrected for Lorentz and polarization effects. ${ }^{26}$ The structure was solved by direct methods ${ }^{27}$ and expanded using Fourier techniques. $^{28}$ The non-hydrogen atoms were refined anisotropically. Hydrogen atoms were refined using the riding model. The final cycle of full-matrix least-squares refinement ${ }^{29}$ on $F^{2}$ was based on 1420 observed reflections and 84 variable parameters and converged. Crystallographic data for the structural analysis reported in this paper have been deposited with the Cambridge Crystallographic Data Centre, CCDC, Number (721559). This data can be obtained free of charge at http://www.ccdc.cam.ac.uk/conts/retrieving.html [or from the Cambridge Crystallographic Data Centre
(CCDC), 12 Union Road, Cambridge CB2 1EZ, UK; fax: +44-1223-336033; email: deposit@ccdc.cam.ac.uk].

Neutral atom scattering factors were taken from Cromer and Waber. ${ }^{30}$ Anomalous dispersion effects were included in $F_{\text {calc }} ;{ }^{31}$ the values for $\Delta f^{\prime}$ and $\Delta f^{\prime \prime}$ were those of Creagh and McAuley. ${ }^{32}$ The values for the mass attenuation coefficients are those of Creagh and Hubbell. ${ }^{33}$ All calculations were performed using the CrystalStructure ${ }^{25,34}$ crystallographic software package except for refinement, which was performed using SHELXL-97. ${ }^{29}$

\section{RESULTS AND DISCUSSION}

\section{IR and UV/vis Spectroscopy}

The Schiff base (bpfd) ligand has a strong absorbance at $1647 \mathrm{~cm}^{-1}$ in the infrared region, confirming the presence of the imine moiety. The stretching vibration of $\mathrm{C}=\mathrm{N}$ and $\mathrm{C}=\mathrm{C}$ of the pyridine ring are observed at 1586 and $1427 \mathrm{~cm}^{-1}$, respectively. Additionally, the UV/vis spectrum has strong absorptions near 272 and $282 \mathrm{~nm}$. These bands are assigned to the ligand centered (LC) or $\pi-\pi^{*}$ transitions. The IR data are consistent with the reported value. $^{35}$

\section{NMR Spectroscopy}

The ${ }^{1} \mathrm{H}$ NMR spectrum for the (bpfd) ligand give signals corresponding to the aromatic protons in the range $7.25-8.59 \mathrm{ppm}$. The ${ }^{1} \mathrm{H}$ NMR signals arising from ethylene protons appear as singlet at $4.02 \mathrm{ppm}$. ${ }^{13} \mathrm{C}$ NMR spectrum supports the formation of the Schiff base (bpfd) ligand. The ${ }^{13} \mathrm{C}$ NMR signals corresponding to the aromatic carbons are visible in the region 117-166 ppm. Signal corresponding to the aliphatic and vinylic carbons are found at 61 and 154 ppm, respectively.

\section{Supramolecular Interactions Involved in the Solid State Structure of (bpfd) Ligand}

A solvent free sample of the $N, N^{\prime}$-[bis(pyridine-2-yl)formylidene] ethane-1,2-diamine ligand (bpfd) (Figure 1) was obtained after crystallization from diethyl ether to give material that was good enough to be examined by the single crystal X-ray technique. The (bpfd) ligand crystallizes in a monoclinic space group $\mathrm{C} 12 / \mathrm{c} 1$ with $a$ $=19.128(2) \AA ; b=5.8776(6) \AA ; c=13.1403(15) \AA ; \alpha=$ $90^{\circ} ; \beta=121.970^{\circ}(4) ; \gamma=90^{\circ}$ and $z=4$. Numerical details of the crystal structure are presented in experimental section. ORTEP drawing of (bpfd) molecular structure is shown in Figure 2. The bond distances and angles for (bpfd) ligand (Tables 1, 2) are as expected. $^{36,37}$ The crystal structure of (bpfd) is an example of compounds with many symmetry-independent mole- 
Table 1. Summary of bond distances $(\AA)$ for (bpfd) ligand

\begin{tabular}{llllll}
\hline atom & atom & distance & atom & atom & distance \\
\hline $\mathrm{N}(1)$ & $\mathrm{C}(1)$ & $1.3459(18)$ & $\mathrm{N}(1)$ & $\mathrm{C}(5)$ & $1.3547(18)$ \\
$\mathrm{N}(2)$ & $\mathrm{C}(6)$ & $1.2715(16)$ & $\mathrm{N}(2)$ & $\mathrm{C}(7)$ & $1.4666(18)$ \\
$\mathrm{C}(1)$ & $\mathrm{C}(2)$ & $1.396(2)$ & $\mathrm{C}(2)$ & $\mathrm{C}(3)$ & $1.391(2)$ \\
$\mathrm{C}(3)$ & $\mathrm{C}(4)$ & $1.394(2)$ & $\mathrm{C}(4)$ & $\mathrm{C}(5)$ & $1.400(2)$ \\
$\mathrm{C}(5)$ & $\mathrm{C}(6)$ & $1.4870(18)$ & $\mathrm{C}(7)$ & $\mathrm{C}(7)$ & $1.5272(14)$ \\
\hline
\end{tabular}

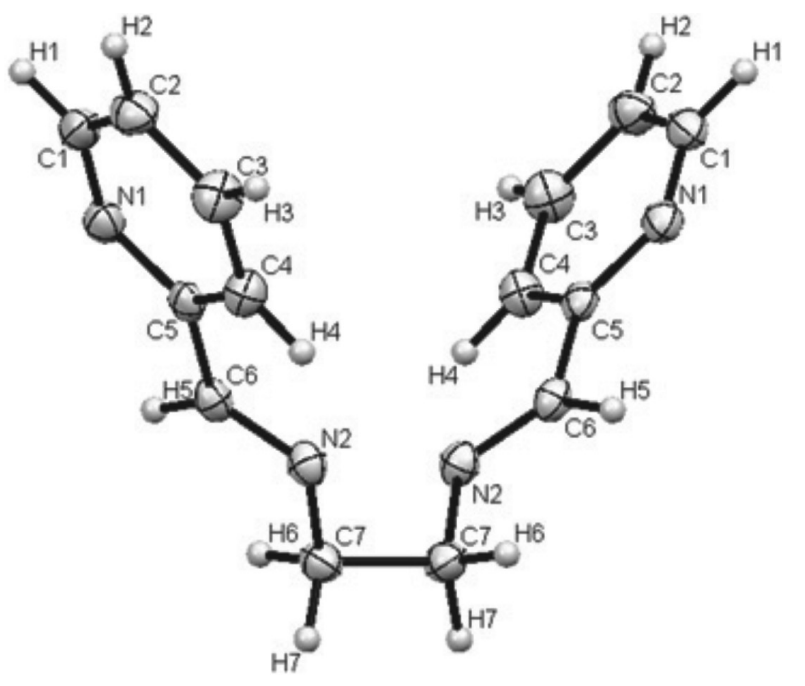

Figure 2. ORTEP drawing of (bpfd). Thermal ellipses are shown in $50 \%$ probability.

cules in the asymmetric unit cell $(Z>2)$. This phenomenon was extensively analyzed by Bernstein et l. $^{38}$ and accordingly reported that high- $Z$ structures have been described as "snapshot pictures" and also as "fossil relics" of early stages in crystallization. Such description has a certain charm. However, as we are almost totally ignorant of the nucleation process, the early stages in crystallization, these picturesque descriptions have the disadvantage that they are almost impossible to confirm or to refute.

Table 2. Summary of bond angles $\left(^{\circ}\right)$ for (bpfd) ligand

\begin{tabular}{llll}
\hline atom & atom & atom & angle \\
\hline $\mathrm{C}(1)$ & $\mathrm{N}(1)$ & $\mathrm{C}(5)$ & $117.22(14)$ \\
$\mathrm{N}(1)$ & $\mathrm{C}(1)$ & $\mathrm{C}(2)$ & $123.44(13)$ \\
$\mathrm{C}(2)$ & $\mathrm{C}(3)$ & $\mathrm{C}(4)$ & $119.27(17)$ \\
$\mathrm{N}(1)$ & $\mathrm{C}(5)$ & $\mathrm{C}(4)$ & $123.33(12)$ \\
$\mathrm{C}(4)$ & $\mathrm{C}(5)$ & $\mathrm{C}(6)$ & $121.60(12)$ \\
$\mathrm{N}(2)$ & $\mathrm{C}(7)$ & $\mathrm{C}(7)$ & $111.46(11)$ \\
$\mathrm{C}(6)$ & $\mathrm{N}(2)$ & $\mathrm{C}(7)$ & $116.99(13)$ \\
$\mathrm{C}(1)$ & $\mathrm{C}(2)$ & $\mathrm{C}(3)$ & $118.56(13)$ \\
$\mathrm{C}(3)$ & $\mathrm{C}(4)$ & $\mathrm{C}(5)$ & $118.16(14)$ \\
$\mathrm{N}(1)$ & $\mathrm{C}(5)$ & $\mathrm{C}(6)$ & $115.07(13)$ \\
$\mathrm{N}(2)$ & $\mathrm{C}(6)$ & $\mathrm{C}(5)$ & $121.82(14)$ \\
\hline
\end{tabular}

Detailed analysis of (bpfd) crystal structure showed the presence of edge-edge $\mathrm{C} 6-\mathrm{H} 5 \ldots \mathrm{N} 1$ centrosymmetric dimer interactions. This centrosymme-tric $\mathrm{C}-\mathrm{H}$... N dimer is composed of $\mathrm{C}-\underline{\mathrm{H}} \ldots \underline{\mathrm{N}}$ and $\underline{\mathrm{C}}-\mathrm{H}$... $\underline{\mathrm{N}}$ interactions with distances of 2.7 and $3.55 \AA$, respec-

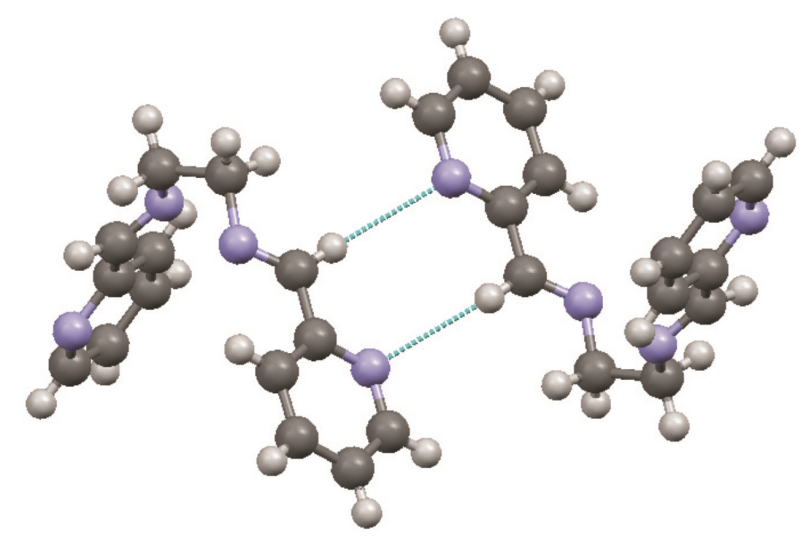

Figure 3. Centrosymmetric dimer composed of two molecules of (bpfd) through $\mathrm{C} 6-\mathrm{H} 5 . . \mathrm{N} 1$ interactions with a bond distance of $2.7 \AA$ and bond angle of $145.68^{\circ}$.

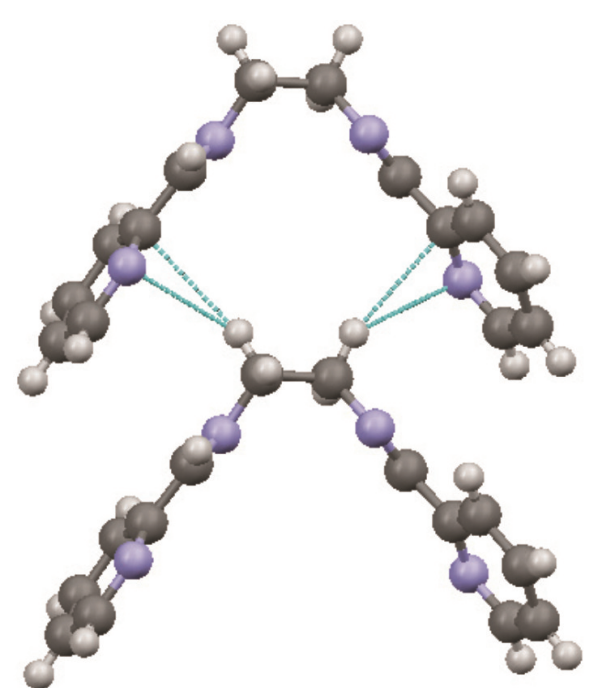

Figure 4. Part of ligand (bpfd) crystal structure showing bifurcated (N1...H7...C5) centrosymmetric dimers formed between methylene hydrogen and pyridine nitrogen with a distance of $2.73 \AA$ and pyridine carbon and methylene hydrogen with a distance of $2.84 \AA$ and N1...H7 ...C5 bond angle of $28.09^{\circ}$. 


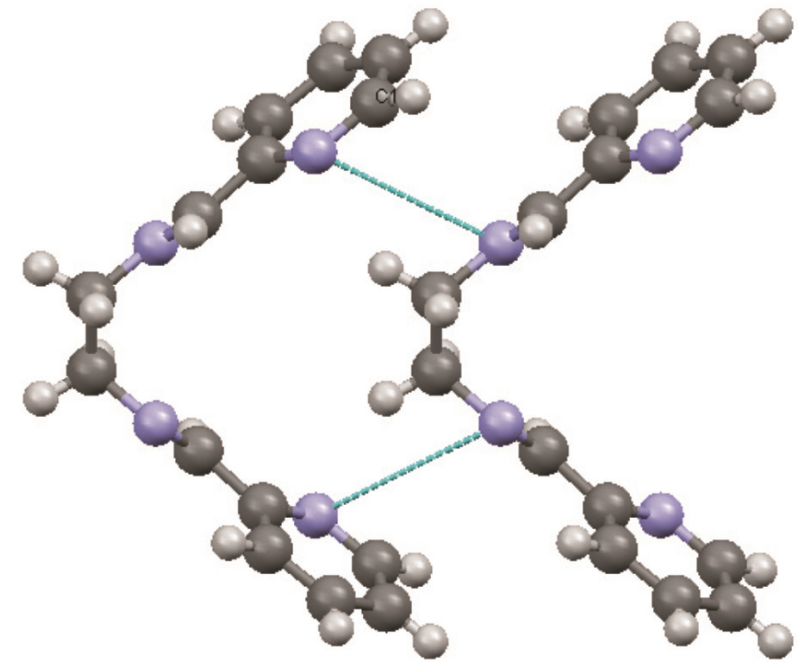

Figure 5. Two molecules of (bpfd) ligand interact together through their nitrogen atoms to form centrosymmetric dimer with a distances of $3.92 \AA$.

tively and $\mathrm{C} 6-\mathrm{H} 5 \ldots \mathrm{N} 1$ bond angle of $145.68^{\circ}$ as shown in Figure 3.

In addition, detailed analysis of (bpfd) crystal structure showed the presence of a layer arrangement between the aromatic ring and aliphatic methyl hydrogen to produce the bifurcated centrosymmetric $\mathrm{C}-\underline{\mathrm{H}} \ldots \underline{\mathrm{N}}$ and $\mathrm{C}-\underline{\mathrm{H}} \ldots \underline{\mathrm{C}}$ interactions with distances of 2.73 and $2.84 \AA$, respectively as shown in (Figure 4). In addition, face-face nitrogen-nitrogen interaction is observed in the crystal structure of (bpfd) through $\mathrm{C} 1-\mathrm{N} 1 \ldots \mathrm{N} 2$ to form centrosymmetric dimer. The centrosymmetric $\mathrm{C} 1-\mathrm{N} 1 \ldots \mathrm{N} 2$ dimer had $\mathrm{C}-\underline{\mathrm{N}}$... $\underline{\mathrm{N}}$ interactions with a distance of $3.92 \AA$ and bond angle of $63.92^{\circ}$ as shown in Figure 5 . This centrosymmetric dimer is stabilized by mean of face-face $\pi$-stacking interactions between the pyridine rings and the $\mathrm{C} 1-\mathrm{N} 1$ of each dimer with distances of $3.92 \AA$ with offset angle of $63.92^{\circ}$ (Figure 5). Such interactions will stabilize the formation of the dimer. Furthermore, edge-edge nitrogen-nitrogen interaction is observed between two molecules of (bpfd) through $\mathrm{C} 1-\mathrm{N} 1 \ldots \mathrm{N} 1-\mathrm{C} 1$ interaction with a bond distance of $3.89 \AA$ and $\mathrm{C} 1-\mathrm{N} 1 \ldots \mathrm{N} 1$ bond angle of $68.79^{\circ}$ as shown in Figure 6.

\section{CONCLUSION}

The structure of the Schiff base, $N, N^{\prime}$-[bis(pyridine-2-yl) formylidene] ethane-1,2-diamine (bpfd) has been characterized by NMR spectroscopy and a single-crystal X-ray diffraction. The non-covalent supramolecular chemistry involved in the crystal structure of this ligand has been carefully investigated. The analysis of bpfd ligand crystal structure demonstrates the presence of different supramolecular synthons such as edge-edge (aliph-

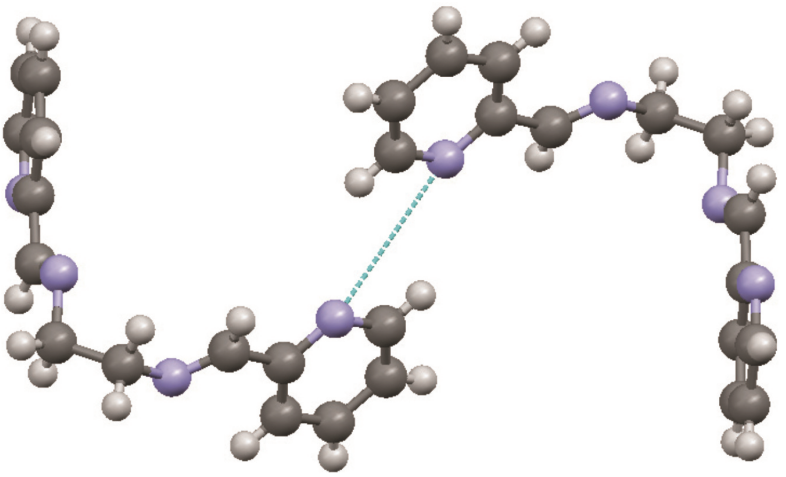

Figure 6. Edge-edge nitrogen-nitrogen interaction between two molecules of (bpfd) ligand with a distance of $3.89 \AA$.

$\mathrm{H} . . \mathrm{N} 1$ and $\mathrm{C} 1-\mathrm{N} 1 \ldots \mathrm{N} 1-\mathrm{C} 1)$ and face-face $\mathrm{C} 1-\mathrm{N} 1 \ldots \mathrm{N} 2$ centrosymmetric dimer interactions. The crystal structure of (bpfd) is found to be a new example of compounds with many symmetry-independent molecules in the asymmetric unit cell $(Z>2)$. Different motifs of non-covalent interactions were observed and reported in terms of crystal engineering and supramolecular chemistry.

Acknowledgements. This work is supported by the Deanship of Scientific Research at Mu'tah University.

\section{REFERENCES}

1. S. H. Rahaman, R. Ghosh, and B.K. Ghosh, Inorg. Chem. Commun. 9 (2006) 1011-1014.

2. T. K. Karmakar, B. K. Ghosh, A. Usman, H. K. Fun, E. Riviere, T. Mallah, G. Aromi, and S. K. Chandra, Inorg. Chem. 44 (2005) 2391-2399, and refs therein.

3. P. A. Vigato, S. Tamburini, and L. Bertolo, Coord. Chem. Rev. 251 (2007) 1311-1492.

4. R. Drozdzak, B. Allaert, N. Ledoux, I. Dragutan, V. Dragutan, and F. Verpoort, Coord. Chem. Rev. 249 (2005) 3055-3074.

5. J. Lewinski, J. Zachara, I. Justyniak, and M. Dranka, Coord. Chem. Rev. 249 (2005) 1185-1199.

6. C.-M. Che and J. S. Huang, Coord. Chem. Rev. 242 (2003) 97-113.

7. B. H. Mehta and A. S. Salunke, Asian. J. Chem. 18 (2006) 1326-1334.

8. R. V. Singh and M. K. Biyala, Phosphorus Sulfur Silicon Relat. Elem. 181 (2006) 1477-1491.

9. Z. H. Chohan, M. Arif, Z. Shafiq, M. Yaqub, and C. T. Supuran, J. Enzyme Inhib. Med. Chem. 21 (2006) 95-103.

10. H. M. Parekh, P. K. Panchal, and M. N. Patel, Toxicol. Environ. Chem. 88 (2006) 579-586.

11. V. N. Pathak, C. K. Oza, M. Jain, N. Jain, and V. M. Rao, Chemistry (Rajkot, India), 3 (2006) 119.

12. S. Adsule, V. Barve, D. Chen, F. Ahmed, Q. P. Dou, S. Padhye, and F. H. Sarkar, J. Med. Chem. 49 (2006) 7242-7246.

13. X. Zhong, J. Yi, J. Sun, H. L. Wei, W. S. Liu, and K. B. Yu, Eur. J. Med. Chem. 41 (2006) 1090-1092.

14. G. Garcia-Friaza, A. Fernàndez-Botello, J. M. Perez, M. J. Prieto, and V. Moreno, J. Inorg. Biochem. 100 (2006) 1368-1377.

15. S. Handa, V. Gnanadesikan, S. Matsunaga, and M. Shibasaki, J. 
Am. Chem. Soc. 129 (2007) 4900-4901.

16. M. Salavati-Niasari, M.Shaterian, M. R. Ganjali, and P. Norouzi, J. Mol. Catal. A: Chem. 261 (2007) 147-155.

17. D. J. Darensbourg, E. B. Frantz, and J. R. Andreatta, Inorg. Chim. Acta 360 (2007) 523-528.

18. M. Ul-Haque, F. A. Hart, and C. N. Caughlan, J. Chem. Soc. D: Chem. Commun. (1970) 1240-1241.

19. S. Pal and S. Pal, Polyhedron 22 (2003) 867-873.

20. M. G. Drew, M. R. Foreman, M. J. Hudson, and K. Kennedy, Inorg. Chim. Acta 357 (2004) 4102-4112.

21. N. C. Habermehl, P. M. Angus, N. L. Kilah, L. Norén, A. D. Rae, A. C. Willis, and S. B. Wild, Inorg. Chem. 45 (2006) 1445-1462.

22. M. Habib, T. K. Karmakar, G. Aromí, J. Ribas-Ariňo, H-K. Fun, S. Chantrapromma, and S. K. Chandra, Inorg. Chem. 47 (2008) 4109-4117.

23. W. Al-Btoush, Synthesis, Characterization and Supramolecularity of Schiff Base ligand. Transition Metal Complexes of Schiff Base Ligands. Master Thesis, Mu'tah University, Jordan, 2009.

24. T. K. Karmakar, S. K. Chandra, J. Ribas, G. Mostafa, T. H. Lu, and B. K. Ghosh, Chem. Commun. (2002) 2364-2365.

25. Crystal structure 3.7.0: Crystal structure analysis package, Rigaku and Rigaku/MSC (2000-2005) . 9009 New Trails Dr., The Woodlands TX 77381 USA.

26. A. C. Larson, in: F. R. Ahmed (Eds.), Crystallographic Computing, Munksgaard, Copenhagen, 1970, pp 291-294.

27. A. Altomare, G. Cascarano, C. Giacovazzo, A. Guagliardi, M. C. Burla, G. Polidori, and M. Camalli, J. Appl. Cryst. 27 (1994) 435-436. The SIR92 program for automatic solution of crystal structures by direct methods.
28. P. T. Beurskens, G. Admiraal, G. Beurskens, W. P. Bosman, R. de Gelder, R. Israel, and J. M. M. Smits, The DIRDIF-99 program system, technical report of the crystallography laboratory. University of Nijmegen, the Netherlands, 1999.

29. G. M. Sheldrick, SHELX97 and SHELXL97. University of Göttingen, Germany, 1997.

30. D. T. Cromer, J. T. Waber, International tables for X-ray crystallography, Vol. IV. The Kynoch Press, Birmingham, 1974 (Table $2.2 \mathrm{~A})$.

31. J. A. Ibers and W. C. Hamilton, Acta Crystallogr. 17 (1964) 781-782.

32. D. C. Creagh and W. J. McAuley, in: A. J. C. Wilson (Eds.), International tables for crystallography, Vol. C., Kluwer Academic Publishers, Boston, 1992, pp 219-222 (Table 4.2.6.8).

33. D. C. Creagh and J. H. Hubbell, in: A. J. C. Wilson (Eds.), International tables for crystallography, Vol. C., Kluwer Academic Publishers, Boston, 1992, pp 200-206 (Table 4.2.4.3).

34. D. J. Watkin, C. K. Prout, J. R. Carruthers, and P. W. Betteridge, Chemical Crystallography Laboratory. University of Oxford, Oxford, 1996.

35. S. H. Rahaman, R. Ghosh, G. Mostafa, and B. K. Ghosh, Inorg. Chem. Commun. 8 (2005) 1137-1140.

36. S. H. Rahaman, H. Chowdhury, H. L. Milton, A. M. Z. Slawin, J. D. Woollins, and B. K. Ghosh, Inorg. Chem. Commun. 8 (2005) 1031-1035.

37. S. H. Rahaman, R. Ghosh, G. Mostafa, and B. K. Ghosh, Inorg. Chem. Commun. 8 (2005) 700-703.

38. J. Bernstein, J. D. Dunitz, and A. Gavezzotti, Cryst. Growth Des. 8 (2008) 2011-2018. 